\title{
Screening Cover Crops for Soil Macrofauna Abundance and Diversity in Conservation Agriculture
}

\author{
Mutondwa M. Phophi ${ }^{1}$, Paramu L. Mafongoya ${ }^{1}$, Alfred O. Odindo ${ }^{1} \&$ Lembe S. Magwaza $^{1}$ \\ ${ }^{1}$ Department of Crop Science, School of Agricultural, Earth and Environmental Sciences, University of \\ KwaZulu-Natal, Private Bag X01, Scottsville, 3209, Pietermaritzburg, South Africa \\ Correspondence: Department of Crop Science, School of Agricultural, Earth and Environmental Sciences, \\ University of KwaZulu-Natal, Private Bag X01, Scottsville, 3209, Pietermaritzburg, South Africa. E-mail: \\ mutondiwa@gmail.com
}

Received: July 5, 2016 Accepted: August 30, 2017 Online Published: October 14, 2017

doi:10.5539/sar.v6n4p142

URL: https://doi.org/10.5539/sar.v6n4p142

\begin{abstract}
Soil health is important for sustainable crop production. Frequent soil cultivation has a negative impact on soil health, resulting in loss of soil macrofauna. Conservation agriculture can be practiced to improve soil health by improving the abundance of soil macrofauna. Three leguminous cover crops were tested for soil macrofauna abundance Vigna unguiculata, (cowpea) Lablab purpureus L. (dolichos lablab) and Mucuna pruriens (L.) DC (velvet bean). The experiment was done in two contrasting experimental sites of KwaZulu-Natal (Ukulinga and Bergville) in a randomised complete block design replicated three times. Bare plot and herbicide treatments served as controls. Natural fallow was used to make a comparison to all the other treatments. Cowpea (39 species) had the highest soil macrofauna abundance in Bergville. Lablab (57 species) had the highest soil macrofauna in Ukulinga. Cowpea (0.75 species) and lablab (0.61 species) improved soil macrofauna diversity respectively in Bergville. Natural fallow (0.46 species) had the lowest soil macrofauna diversity in Bergville. Lablab (0.56 species) and velvet bean ( 0.74 species) had high soil macrofauna species diversity in Ukulinga. Bare plot $(0.3$ species $)$ had the lowest soil macrofauna species diversity respectively. It can be concluded that cowpea and lablab can be recommended for improving soil macrofauna abundance in conservation agriculture.
\end{abstract}

Keywords: species richness, leguminous cover crops, soil health

\section{Introduction}

Soil macrofauna play an essential role in soil physical, chemical and biological properties, which condition the soil quality and productivity of agro-ecosystem (Blanchart et al., 2007). Sustainable crop productivity in agro-ecosystem relies on soil macrofauna abundance and biodiversity (Lavelle et al., 2006). Soil macrofauna community encompass a wide range of organisms performing various functions such as soil physical and chemical properties (Lavelle et al., 1997). Soil macrofauna plays a major role in soil fertility by enhancing, mixing, macro porosity, and mineralization of organic matter. These processes help to improve soil structure, gaseous exchange, infiltration and water retention and soil chemical properties. In addition soil macrofauna abundance and biodiversity act to prevent pest outbreaks in agro-ecosystems by balancing the predator and herbivore ratio (Tillman et al., 2004).

In the same arid tropical agrosystems, abundance and diversity of soil macrofauna are frequently reduced through habitat structure disturbances of soil organisms by extreme climatic conditions, overgrazing and trampling by cattle, burning of crop residues, ploughing and mechanized seed bed preparation, indiscriminate agrochemical use and monocultures (Brown et al., 2003). Tropical soils devoid of meso and macrofauna are particularly vulnerable to compaction and structural collapse which can impede water infiltration and root growth and contribute to soil erosion and degradation (Lal, 1988).

Conservation agriculture is the use of agricultural practices that result in less disturbance of the soil. It is being promoted to reduce land degradation and to safeguard soil properties including soil macrofauna (Mutema et al., 2013). Conservation agriculture, which has three pillars: minimum tillage, soil cover and crop rotation, is economically friendly because it conserves natural resources (Giller et al., 2009) and could be practiced in order to restore better conditions for soil organisms. Conservation agriculture is known to improve soil fauna activities and soil biological properties than conventional tillage (Busari et al., 2015). 
Cover crops being one of conservation agriculture pillars are known to have an impact in the diversity and abundance of soil fauna. Cover crops such as Mucuna pruriens (L.) DC has been found to increase the abundance of earthworms, centipedes, millipedes and beetles, thus improving the soil structure and the availability of nutrients (Lal, 1988). The use of cover crops to improve soil macrofauna is not well understood in the African continent. The objective of this study was to evaluate the effect of leguminous cover crops on soil macrofauna abundance.

\section{Materials and Methods}

\subsection{Site Description}

The study was carried out in two experimental areas (Bergville and Ukulinga) both situated in KwaZulu-Natal Province in 2015. The two sites were different in soil properties as shown in Table 1. Soil samples were taken prior to commencement of the study as shown in Table 1. Annual rainfall of Bergville was $643 \mathrm{~mm}$ and the temperature ranged from $19.3{ }^{\circ} \mathrm{C}$ to $27.9^{\circ} \mathrm{C}$. Monthly rainfall and temperature of Bergville could not be found. Monthly rainfall and temperature for Ukulinga are shown in Table 2.

Table 1. Soil chemical and physical properties in Bergville and Ukulinga before planting

\begin{tabular}{lllllllll}
\hline Site & sand \% & silt \% & clay \% & $\mathrm{pH}(\mathrm{KCI})$ & Total N\% & Org C \% & $\mathrm{P}(\mathrm{mg} / \mathrm{kg})$ & $\mathrm{K}(\mathrm{mg} / \mathrm{kg})$ \\
\hline Bergville & 25 & 16 & 59 & 3.83 & 0.23 & 2.2 & 7.9 & 165 \\
Ukulinga & 38 & 26 & 36 & 4.80 & 0.23 & 2.5 & 13.59 & 133 \\
\hline
\end{tabular}

Table 2. Monthly rainfall and temperature in Ukulinga 2015

\begin{tabular}{lllllllll}
\hline & Jan & Feb & Mar & Apr & May & Jun & Jul & Aug \\
\hline Min temperature ${ }^{\circ} \mathrm{C}$ & 16.03 & 15.60 & 15.68 & 12.02 & 11.88 & 8.93 & 8.94 & 10.92 \\
Max Temperature ${ }^{\circ} \mathrm{C}$ & 27.66 & 26.47 & 27.04 & 23.90 & 25.96 & 22.20 & 21.13 & 24.51 \\
Rainfall mm & 132.80 & 143.00 & 82.20 & 0 & 5.02 & 2.02 & 32.99 & 3.04 \\
\hline
\end{tabular}

\subsection{Experimental Design}

Three cover crops were evaluated for biomass and soil macrofauna abundance. The cover crops used were (1) Vigna unguiculata (L.) (cowpea) Walp, (2) Mucuna pruriens (L.) DC (velvet bean), and (3) Lablab purpureus (L.) (dolichous). The treatments were laid in a randomized complete block design and replicated three times. The total number of treatments were five. Bare plot and herbicide treatments served as control where no cover crops were grown. Samples were also taken from the natural fallow, outside the experimental site for comparison with the treatments.

\subsection{Land Preparation and Crop Management}

Each gross plot size was $10 \mathrm{~m}$ x $5 \mathrm{~m}$. Glyphosate was applied once in herbicide treatment at a recommended rate of $1.5 \%$ per $10 \mathrm{~L}$. The maize and cover crops were planted at the same time in holes opened up by a hand hoe. Planting was done during the second week of January. The maize cultivar used was Nelson's Choice open pollinated variety, planted at a spacing of $75 \mathrm{~cm}$ x $35 \mathrm{~cm}$. All cover crops were planted at a spacing of $15 \mathrm{~cm} \times$ $30 \mathrm{~cm}$ to create a dense cover. Superphosphate fertilizer (10.2) was applied during planting at $20 \mathrm{~kg} / \mathrm{ha}$ in Ukulinga and $55 \mathrm{~kg} / \mathrm{ha}$ in Bergville. Weeding was done once by hand hoeing after 4 weeks of planting. Urea (46\% $\mathrm{N})$ was applied two days after weeding at a recommendation of $120 \mathrm{~kg} / \mathrm{ha}$ to maize crop. Maize planted in Bergville did not germinate. In Ukulinga, maize germinated. However, there was no yield collected due to uncontrollable circumstances of wild pigs that fed on maize before harvesting.

\subsection{Sample Collection and Data Analysis}

Soil samples were taken to a depth of $15 \mathrm{~cm}$ prior commencement of the study for analysis. The dry matter production for cover crops was determined at 8,12 and 16 weeks after planting. Cover crop biomass was estimated from a sample by harvesting the above-ground vegetative growth in a quadrat of $0.5 \mathrm{~m}^{2}$. The quadrat was placed randomly on three sampling points in each plot. The cover crop dry matter was oven dried at $70{ }^{\circ} \mathrm{C}$ for 72 hours. Soil monoliths were taken from each plot using metallic monoliths. The soil monoliths were taken three times randomly within each plot at least $2 \mathrm{~m}$ apart. The soil monolith was driven into the soil using a metallic hammer. The size of the monolith was $20 \mathrm{~cm}$ x $20 \mathrm{~cm} \times 20 \mathrm{~cm}$. The soil was removed from the monolith and soil macrofauna were hand-sorted from each sample. Soil macrofauna found was placed in bottles with $70 \%$ alcohol (Dangerfield, 1993). Soil macrofauna diversity was calculated by Shannon-Wiener diversity index using EstimateS version 9.1.0 (Colwell, 2013). Soil macrofauna species richness was calculated by Margalef Index 
(Margalef, 1958) using EstimateS version 9.1.0 (Colwell, 2013). Data was then subjected to Genstat $14^{\text {th }}$ edition for analysis of variance (ANOVA). Poisson distribution with log link function and likelihood type iii test was used to analyze soil macrofauna abundance using Generalized Linear Models (GLM) in SPSS version 23.

\section{Results and Discussion}

\subsection{Cover Crop Biomass Accumulation}

There was no significant interaction between treatments and sampling time in both experimental sites $(\mathrm{P}>0.05)$. Cover crop biomass showed significant difference across treatments in both sampling sites $(\mathrm{P}<0.05)$ (Table 3). In Bergville, velvet bean $(0.72 \mathrm{t} / \mathrm{ha})$ had the greatest biomass and was significantly different to cowpea $(0.59 \mathrm{t} / \mathrm{ha})$ and lablab (0.65 t/ha). In Ukulinga, velvet bean had the highest biomass (1.59 t/ha) and was significantly different to cowpea $(0.98 \mathrm{t} / \mathrm{ha})$ and lablab $(0.88 \mathrm{t} / \mathrm{ha})$ which showed no significant difference. The highest biomass accumulation of velvet bean was attributed to its robust growth habit. This gave it an advantage to do best even in acidic soils of Bergville. The results relate well to the findings of Malama and Kondowe (2002) who reported that Mucuna pruriens (L.) DC appears to be ideal for high biomass accumulation in acidic soils. Velvet bean also showed a robust growth habit in the dry soils of Ukulinga which resulted as the crop with highest biomass accumulation. The high temperatures in the early months after planting could have influenced the fast growth of velvet bean resulting to high biomass. Teasdale et al. (2007) also supports that velvet bean is well adapted to dry hot conditions. Cowpea is said to be well adapted in acidic soils however, it gave the lowest biomass accumulation in Bergville.

Table 3. Cover crop biomass accumulation in Bergville and Ukulinga

\begin{tabular}{lll}
\hline & \multicolumn{2}{l}{ Biomass in $\mathrm{t} / \mathrm{ha}$} \\
\hline Treatment & Bergville & Ukulinga \\
\hline Cowpea & 0.59 & 0.98 \\
Lablab & 0.65 & 0.88 \\
Velvet bean & 0.72 & 1.59 \\
SE & 0.03 & 0.30 \\
LSD $(\mathrm{P} \leq 0.05)$ & 0.05 & 0.39 \\
\hline
\end{tabular}

\subsection{Soil Macrofauna Species Abundance}

There was no significant interaction between treatments and sampling time in both sites Ukulinga and Bergville $(\mathrm{P}>0.05)$. Treatments showed significant difference in Ukulinga $(\mathrm{P}<0.05)$ (Table 4). The lowest total count of soil macrofauna species abundance was found in the natural fallow (15). The highest total count of soil macrofauna species abundance was found in lablab (57). Lablab had the highest soil macrofauna species abundance because of the cover it formed which was spreading and dense. This managed to improve the microclimate and the habitat which might have led to conservation of soil moisture and less fluctuation of soil temperature. Studies by (Staley et al., 2007) also showed that soil macrofauna are sensitive to low soil moisture conditions. The natural fallow had the lowest soil macrofauna species abundance. It was dominated Tagetes minuta $\mathrm{L}$. This weed produces volatile oils which have a suppressive effect against soil organisms (Mohamed et al., 2000).

There was significant difference in soil macrofauna abundance within treatments in Bergville $(\mathrm{P}<0.05)$ (Table 4). The lowest total count of soil macrofauna species abundance was found in the natural fallow (9). The highest total count of soil macrofauna species abundance was found in cowpea treatment (39). The environment created by cowpea and lablab cover crops influenced the survival and abundance of the soil macrofauna. The natural fallow was dominated by grass species and these resulted in low soil macrofauna species abundance due to poor cover formed.

Table 4. Soil macrofauna species abundance in Bergville and Ukulinga (Total counts per $\mathrm{m}^{2}$ )

\begin{tabular}{lll}
\hline Treatment & Bergville & Ukulinga \\
\hline Bare plot & 30 & 42 \\
Cowpea & 39 & 51 \\
Lablab & 36 & 57 \\
Velvet bean & 30 & 54 \\
Herbicide & 33 & 54 \\
Natural fallow & 9 & 15 \\
\hline
\end{tabular}


The proportion of soil macrofauna species abundance in Ukulinga showed significant difference within soil macrofauna species $(\mathrm{P}<0.05)$ (Table 5). Woodlice had high occurrence $(29.7 \%)$ and was followed by ants $(25.3 \%)$ and beetles $(18.7 \%)$. Centipedes, earthworms and termites had a low occurrence throughout the season.

Proportion of soil macrofauna occurrence in Bergville also showed significant difference $(\mathrm{P}<0.05)$ (Table 5). Beetles had the highest percentage of occurrence throughout the season (37.3\%) and were followed by ants which occurred $25.4 \%$ throughout the season. Centipedes, earthworms, termites and millipedes had a low occurrence throughout the season and this could have been influenced by the soil $\mathrm{pH}$ in Bergville.

The most abundant soil macrofauna species at both sites were ants followed by Beetles. At Ukulinga there were more millipedes compared to Bergville (Table 5). Woodlice were high in abundance in Ukulinga. Woodlice were not detected in Bergville. Probably the high abundance of woodlice at Ukulinga could be explained by high $\mathrm{pH}$ levels compared to acidic condition at Bergville. This is an area which needs further research. The low occurrence of earthworms and termites resulted from low acidic conditions at both sites as it has been shown by Lavelle et al. (1995).

Table 5. Proportion of soil marofauna species abundance occurrence in Bergville and Ukulinga

\begin{tabular}{lll}
\hline Species & Bergville & Ukulinga \\
\hline Ants & 25.4 & 25.3 \\
Beetle & 37.3 & 18.7 \\
Centipede & 1.7 & 1.1 \\
Earthworm & 3.4 & 3.3 \\
Millipedes & 1.7 & 13.2 \\
Termites & 3.4 & 2.2 \\
Woodlice & & 29.7 \\
\hline
\end{tabular}

\subsection{Soil Macrofauna Diversity}

There was a significant interaction between soil macrofauna diversity and sampling time in Bergville $(\mathrm{P}<0.05)$ (Table 6). Velvet bean had the lowest diversity of soil macrofauna (0 species) in week 8 and was significantly different to the rest of the treatments. The highest soil macrofauna diversity was found in bare plot ( 0.90 species). In week 12 , herbicide had the lowest soil macrofauna diversity ( 0.23 species) and was not significantly different to lablab treatment $(0.38$ species). Cowpea had the highest soil macrofauna diversity ( 0.96 species) and was not significantly different to bare plot ( 0.86 species), velvet bean ( 0.79 species) and natural fallow ( 0.69 species). At week 16 velvet bean, bare plot and natural fallow had the lowest soil macrofauna diversity of 0 species. The highest diversity was found in lablab (0.67 species).

Bare plot and herbicide showed significant difference and were decreasing across sampling times. Cowpea obtained the highest soil macrofauna diversity in week 12 ( 0.96 species) and the lowest was found in week 16 (0.49 species). Lablab had the lowest soil macrofauna diversity at week 12 (0.38 species) and the highest was found in week 8 ( 0.79 species). Velvet bean had the highest soil macrofauna diversity at week 12 ( 0.79 species). The natural fallow was constant at Week 8 and week 12 (0.69 species).

Cowpea is known for a dense cover it produces. In Bergville cowpea had the highest species diversity compared to velvet bean. Although velvet bean had the highest biomass at Bergville, it had the lowest diversity of soil macrofauna. Both cover crops had a dense ground cover at Bergville. However this variation in soil macrofauna diversity could be attributed to sampling error where the three monoliths were placed in the net plot and also due to the clustered and distribution of soil macrofauna in the field (Sileshi \& Mafongoya, 2006). At week 16, cowpea had a reduction of soil macrofauna species diversity and this could be attributed to the fact that cowpea started dropping its leaves earlier than lablab. 
Table 6. Soil macrofauna species diversity in Bergville

\begin{tabular}{llll}
\hline \multicolumn{4}{l}{ Time of sampling } \\
\hline Treatment & week 8 & week 12 & week 16 \\
\hline Bare plot & 0.90 & 0.86 & 0.00 \\
Cowpea & 0.81 & 0.96 & 0.49 \\
Lablab & 0.79 & 0.38 & 0.67 \\
Velvet bean & 0.00 & 0.79 & 0.00 \\
Herbicide & 0.76 & 0.23 & 0.10 \\
Natural fallow & 0.69 & 0.69 & 0.00 \\
SE & 0.19 & & \\
LSD $(\mathrm{P} \leq 0.05)$ & 0.31 & & \\
\hline
\end{tabular}

There was significant interaction of soil macrofauna diversity between treatments and sampling times in Ukulinga $(\mathrm{P}<0.05)$ (Table 7). At week 8 bare plot had 0 soil macofauna diversity and was significantly different to the rest of the treatments. The highest soil macrofauna diversity was found in velvet bean (1.00 species). At week 12 natural fallow had 0 soil macrofauna diversity and was significantly different to the rest of the treatments. The highest soil macrofauna diversity was found in herbicide treatment (1.08 species). Bare plot had the lowest soil macrofauna abundance in week 16 (0.13 species) and was significantly different to the rest of the treatments. The highest soil macrofauna diversity was found in cowpea ( 0.72 species).

Bare plot and cowpea had the lowest soil macrofauna diversity in week 8 respectively $(0 ; 0.41$ species). Lablab and herbicide showed the highest soil soil macrofauna diversity found in week 12 ( $0.66 ; 1.08$ species). Velvet bean had the lowest soil macrofauna diversity in week 12 (0.59 species) and was highest in week 16 (0.65 species). The natural fallow had the lowest soil macrofauna diversity in week 12 (0 species). Week 8 and week 16 were not significantly different.

Soil macrofauna are known to survive better in moist soil conditions (Staley et al., 2007). Velvet bean had high soil macrofauna diversity in week 8 then reduced in week 12 . The reason was due to lack of cover and sampling error.

Table 7. Soil macrofauna species diversity in Ukulinga

\begin{tabular}{llll}
\hline \multicolumn{4}{l}{ Time of sampling } \\
\hline Treatment & week 8 & week 12 & week 16 \\
\hline Bare plot & 0.00 & 0.77 & 0.13 \\
Cowpea & 0.41 & 0.43 & 0.72 \\
Lablab & 0.55 & 0.66 & 0.47 \\
Velvet bean & 1.00 & 0.59 & 0.65 \\
Herbicide & 0.75 & 1.08 & 0.64 \\
Natural fallow & 0.69 & 0.00 & 0.44 \\
SE & 0.20 & & \\
LSD $(\mathrm{P} \leq 0.05)$ & 0.33 & & \\
\hline
\end{tabular}

\subsection{Soil Macrofauna Species Richness}

There was significant difference with soil macrofauna species richness across treatments in Bergville $(\mathrm{P}<0.05)$ (Table 8). Velvet bean had the lowest soil macrofauna species richness $(0.02$ species $)$ and was significantly different to herbicide treatment $(0.79$ species $)$. The highest soil macrofauna species richness was found in herbicide (0.79 species). The herbicide was applied once and was never repeated as per recommendation. Species richness in natural fallow was lower than the herbicide treatment. This could be attributed to that in herbicide treatment, broadleaf weeds dominated and they formed a good ground cover whereas in the natural fallow it was dominated by grasses which did not form a dense canopy cover. This area needs further research.

Cowpea and lablab had the highest soil macrofauna species richness compared to velvet bean (Table 8) in Bergville. Both cover crops produced a dense cover that favored species richness of soil macrofauna. Velvet bean had the lowest soil macrofauna species richness. The reason for this is not known at the moment it needs further investigation. 
Table 8. Soil macrofauna species richness in Bergville

\begin{tabular}{ll}
\hline Treatment & Species richness \\
\hline Bare plot & 0.10 \\
Cowpea & 0.48 \\
Lablab & 0.42 \\
Velvet bean & 0.02 \\
Herbicide & 0.79 \\
Natural fallow & 0.06 \\
SE & 0.94 \\
LSD $(\mathrm{P} \leq 0.05)$ & 0.36 \\
\hline
\end{tabular}

There was no significant interaction with soil macrofauna species richness between treatment and sampling time in Ukulinga ( $\mathrm{P}>0.05)$. There was also no significant difference with soil macrofauna species richness across treatments $(\mathrm{P}>0.05)$.

Sampling time showed significant difference with soil macrofauna species richness at $\mathrm{P}<0.05$ (Table (9). Week 16 had the lowest soil macrofauna species richness $(0.02$ species) and was significantly different from week 8 and week 12 which did not show significant difference. The highest soil macrofauna species richness was found in week 8 and 12 and there were no significant difference within these two sampling times $(0.20$ species $)$.

Seasonal and microhabitat (soil moisture and temperature) variability may affect distribution patterns of soil macrofauna (Doblas-Miranda et al., 2009). Therefore it is hypothesized that the decrease in soil macrofauna richness across sampling time in Ukulinga could be possibly caused by decrease in moisture and temperature.

Table 9. Soil macrofauna species richness in Ukulinga

\begin{tabular}{ll}
\hline Sampling time & Species Richness \\
\hline Week 8 & 0.20 \\
Week 12 & 0.19 \\
Week 16 & 0.02 \\
SE & 0.37 \\
LSD $(\mathrm{P} \leq 0.05)$ & 0.15 \\
\hline
\end{tabular}

\section{Conclusion}

Soil macrofauna are responsible for maintenance of soil physical properties, short term recycling of nutrients and increased water infiltration and retention. This study has shown that cover crops have significant effect on soil macrofauna abundance, species richness and diversity. There were significant differences between the cover crops on soil macrofauna abundance, species richness and diversity. In Bergville site, the major fauna species were ants, beetles, earthworms and termites while at Ukulinga site the most abundant species were ants, termites and millipedes. In Bergville Cowpea and lablab had the highest species richness followed by velvet bean and natural fallow. The same trend was observed for species diversity in Bergville. These results can be attributed partly to the growth habit of the cover crops. Cowpea and lablab had a growth habit which can be described as spreading on the ground which in turn created a dense canopy. This ground cover could have created a macro habitat of low soil temperature and higher soil moisture which favored growth of soil macrofauna species. Velvet bean had creeping growth habit. This created an open space with less cover. This could have led to high soil temperature and less soil moisture which did not favor growth of soil macrofauna species. Hence cowpea and lablab are recommended as cover crops in conservation agriculture for improvement of macrofauna abundance, species richness and diversity.

\section{Future research needs}

More detailed research would be necessary to identify soil macrofauna groups to genera and species level and to link these species diversity to functional ecology and beneficial purposes to agriculture. Furthermore, it would be of great interest to identify groups or species that can be used to characterize biological health of the soil and its sustained productivity. These species may serve as indicators on environmental conditions or particular ecological properties in the soil.

\section{Acknowledgement}

The study was supported by National Research Foundation through the South African Research Chair: 
Agronomy and Rural Development at the University of KwaZulu-Natal, in South Africa. We would like to thank Bergville farmers for providing us with land and field trial management.

\section{Reference}

Blanchart, E., Villenave, C., Villatoux, A., Barthes, B., Gardin, C., Azontonde, A., Fellera, C. (2006). Long term effect of a legume cover crop (Mucuna pruriens varutilitis) on the communities of soil macrofaun and nematofauna, under maize cultivation in Southern Benin. Applied Soil Ecology, 42, 136-144. https://doi.org/10.1016/j.ejsobi.2006.07.018

Brown, G., Benito, N.P., Pasini, A., Sautter, K. D., Guimaraes, M. F., \& Tores, E. (2003). No tillage greatly increases earthworm populations in Parana State, Brazil: the seventh international symposium on earthworm ecology cardiff wales 2002. Pedobiologia, 47, 764-771. https://doi.org/10.1078/0031-4056-00256

Busari, M. A., Kukal, S. S., Kaur, A., Bhatt, R.., \& Dulazi, A. A. (2015). Conservational tillage impacts on soil, crop and the environment. International Soil and Water Conservation Research, 3, 119-129. https://doi.org/10.1016/j.iswcr.2015.05.002

Colwell, R. K. (2013). EstimateS: statistical estimation of species richness and shared species from samples. Version 9 and earlier. User's guide and application. http://purl.oclc.org/estimates

Dangerfield, J. M. (1993). Characterisation of soil fauna communities. In: Report on characterisation of experimental field in KARI farm, Muguya, Kenya (Eds M.R. Rao and R.J. Scholes). ICRAF, Nairobi, Kenya

Doblas-Miranda, E., Sanchez-Pinero, F., \& Gonzales-Megias, A. (2009). Vertical distribution of soil macrofauna in an arid ecosystem: Are litter and belowground compartmentalized habitats? Pedobiologia, 52, 361-373. https://doi.org/10.1016/j.pedobi.2008.11.006

Giller, K.E., Witter, E., Corbeels, M., \& Tittonell, P. (2009). Conservation agriculture and smallholder farming in Africa: the heretics' view. Field Crops Research, 114, 23-34. https://doi.org/10.1016/j.fcr.2009.06.017

Lal, R., (1988). Effects of macrofauna on soil properties in tropical ecosystems. Agriculture, Ecosysytem and Environment, 24, 101-116. http://dx.doi.org/10.1016/0167-8809 (88)90059-X

Lavelle, P., Bignell, D., Lepage, M., Wolters, V., Rober, P., Incson, P., Heal, O. W., \& Dhillion, S. (1997). Soil function in a changing world: the role of inverterbrate ecosystem engineers. European Journal of Soil Biology, 33, 159-195.

Lavelle, P., Chauvel, A., \& Fragoso, C. (1995). Faunal activity in acid soils. Developments in plant and Soil Sciences, 64, 210-211. https://doi.org/10.1007/978-94-011-0221-6_29

Lavelle, P., Decaens, T., Aubert, M., Barota, S., Blouin, M., Bureau, F., Margerie, P., Mora, P., \& Rossic, J. P. (2006). Soil invertebrates and ecosystem services. European Journal of Soil Biology, 42, 3-5. https://doi.org/10.1016/j.ejsobi.2006.10.002

Malama, C., \& Kondowe, K. (2003). Performance of green manures and grain legumes on severely acidic soils in Northern Zambia, and their effect on soil fertility improvement: In Waddington, S.R (ed) Grain legumes and green manures for soil fertility in Southern Africa: taking stock of progress. Proceedings of a Conference held 8-11 October 2002 at the Leopard Rock Hotel, Vumba, Zimbabwe. Soil Fert Net and CIMMYT-Zimbabwe 185-196

Margalef, R. (1958). Information theory in ecology. Gen. Systems, 3, 36-71

Mohamed, M. A. H., Harris, P. J. C., \& Henderson, J. (2000). In vitro selection and characterization of a drought tolerant clone of Tagetes minuta. Plant Science, 159, 213-222. https://doi.org/10.1016/S0168-9452(00)00339-3

Mutema, M., Mafongoya, P. L., Nyagumbo, I., \& Chikukura, L. (2013). Effects of crop residues and reduced tillage on macrofauna abundance. Journal of Organic Systems, 8, 5-16

Sileshi, G., \& Mafongoya, P. L. (2006). Variation in macrofaunal communities under contrasting land use system in eastern Zambia. Applied Soil Ecology, 33, 49-60. https://doi.org/10.1016/j.apsoil.2005.09.003

Staley, J. T., Hodgson, C. J., Mortimer, S. J., Morecrof, M. D., Masters, G. J., Brown, V. K., \& Taylor, M. E. (2007). Effects of summer rainfall manipulations on the abundance and vertical distribution of herbivorous soil macro-inverterbrates. European Journal of Soil Biology, 43, 189-198.

https://doi.org/10.1016/j.ejsobi.2007.02.010 
Teasdale, J. R., Brandsaeter, L. O., Calegari, A., \& Neto, F. S. (2007). Cover crops and weed management: Non-chemical weed management: principles, concepts and technology. CAB International. https://doi.org/10.1079/9781845932909.0049

Tillman, G., Schmberg, H., Phatak, S., Mullinix, B., Lachnicht, S., Timper, P., \& Olson, D. (2004). Influence of cover crops on insect pest and predators in conservation tillage cotton. Journal of Economic Entomology, 97, 1217-1232. https://doi.org/10.1093/jee/97.4.1217

\section{Copyrights}

Copyright for this article is retained by the author(s), with first publication rights granted to the journal.

This is an open-access article distributed under the terms and conditions of the Creative Commons Attribution license (http://creativecommons.org/licenses/by/3.0/). 